\title{
The night I lost my freedom, and got it back again
}

Daylight is filtering through the thick glass brick window with its watery, wavy pattern. I gaze up at the patch of shifting light, mesmerised by its refraction. I feel safe for the first time in weeks. I'm completely alone now. The precarious scaffolding I was clinging to has finally collapsed. I'm on the ground, with nowhere to fall. There's no way of pretending I'm coping any more.

Small rooms with few distractions encourage contemplation. I'm familiar with places like this. As a police officer, I locked people into cells, then let them out again, spending most of my time on the other side of the door. Later, as a student social worker, I worked in a maximum-security prison on placement, then went on retreat in a convent straight afterwards. The nun's cell I slept in was so small I could touch both walls if I stretched out my arms. In this tiny austere space, there's a peculiar sense of sanctuary, even though objectively I know it's unsafe. I'm being held here.

There's a hard metal and wood bench with a meagre plastic mattress. A horribly exposed stainless steel toilet bowl stands in the corner opposite. It looks almost obscene. As if to confirm that I' $m$ in a police cell, a prisoner is dragged kicking and yelling past the thick metal door. The world is both close at hand and far away in this emotional decompression chamber.

I should feel more frightened than I do. I'm in shock. I think back to answering the door at home to find two police officers standing there. I didn't think they were there because I'd done something wrong. Instead, I ran through all the people who might have died (parents, siblings, children). My partner seemed most likely. He had been missing for hours. I got no answer when I rang his mobile. Voicemail messages were stacking up.

I let out a howl: "He's dead!"

"No, he's safe, but you have to come with us."

The way they spoke made it clear that this was non-negotiable. They told me it had to do with their domestic abuse policy, but I didn't understand how that related to me.

They let me go upstairs on my own to fetch clothes and medication. Only now do I think of the flat roof at the back with a short drop onto the garden. I could have 
escaped, like people do in TV dramas. But I was compliant, even though I didn't understand why I was being taken away.

On the journey to the police station I was slightly euphoric, because I knew my partner was alive. I thought back to the time twenty years before, in the hallway of another house, when I had clung to the phone as I heard the words, "I'm so sorry. I have some very sad news for you..." When I saw the two police officers at my door, I thought, "Oh no, not again.... "

I made polite conversation with the arresting officer. My lack of distress must have seemed odd. I probably appeared to be coping with what was happening, but I wasn't. When we arrived, I stood next to another detained person in front of a tall counter, giving my details to the custody officer and being told my rights. It seemed totally unreal. I used to be a police officer yet here I am, on the wrong side of the law. I'm not a typical offender; if anything, I'm hyper law abiding. I get teased because I won't walk on the grass if there's a sign telling me not to. It's Kafkaesque not knowing what I'm supposed to have done. Presumably, they think I must know.

The last few weeks have been a bit of a blur. I've been running faster and faster to keep up. I manage a homelessness service, where I've been battling a drug ring almost single-handed. I've been working 50 -hour weeks, as well as being on call and dealing with incidents in the middle of the night.

I try to think, think, think. My mind tracks back to an evening a couple of weeks ago when I completely lost control. This has only happened twice before, in my teens and in my thirties. There have been other, less major outbursts, but never at school or at work, only ever at home in private.

Being overcome by a surge of emotion so strong I couldn't hope to control it terrified both me and my partner. We were in a dreadful bind because I couldn't calm down until I was alone, and he was afraid to leave me. But eventually the overwhelming emotion subsided. My partner was terribly upset. This was something I'd warned him about when we met. I knew it might destroy our relationship one day, but I didn't understand it, it was outside my control.

Of course. That must be why l'm here.

When everything else has been stripped away, minutiae assume significance. A microwave meal and white plastic fork are handed through the hatch, and I finally give into a long pee in spite of the lack of privacy. I lie on the hard bench with the 
thin blanket over me. It is dark and I drift in and out of sleep. At intervals, there are muffled explosions of noise in the corridor. I flinch and brace myself.

Suddenly, there's a harsh metallic jangling and clanking at the door. It is opened and I'm told to stand up and come out of my tiny sanctuary. I emerge bleary-eyed and barely awake into the brightly-lit, shiny-floored corridor. We walk past cells with shoes outside the doors, and end up in an interview room.

It's 1.30am. The police officer interviewing me is cynical and hostile, a type I worked with in the job. Nothing I say will wash. Silence is the best option, but that will make him angry. There's something familiar about him. What is it? Misogyny? I feel desperately vulnerable and alone. I'm not sure what makes me ask to see the police doctor, but instinctively I know it's the right thing to do.

The doctor's concern for my welfare shatters my brittle veneer of coping and I break down. When I'm calm, he reminds me of my right to seek legal advice and be accompanied during questioning. How ridiculously naïve of me not to have done this from the start. This isn't the first time l've thought I can manage a situation myself, when I'm way out of my depth. I'm returned to the interview room, where I tell the belligerent police officer that I want to see the duty solicitor. I sense his fury, but he has no choice but to send me back to my cell to wait. The solicitor listens patiently as I describe how life seemed to return to normal after I lost control, except I couldn't find any of our kitchen knives. My partner has seemed depressed and distant, but we've been sort of okay. Untangling what's going on is impossible; what matters most is getting my freedom back.

We go back into the interview room and the solicitor reads out a prepared statement. Then the questioning begins again. This time it's, "no comment," "no comment." I sense the police officer's irritation, but there's nothing he can do. The interview is terminated at 5 am and I'm returned to my cell.

I watch the day dawn. Sunlight filters through the thick glass brick window and dances on the wall. Eventually, the door clangs open and I'm led back to the counter. They try to persuade me to accept a caution, which I know from my police service to refuse. Then it's back to my cell for another long wait. Eventually I'm told there will be no further action, and I'm free to leave.

I emerge blinking into the bright sunshine. Mingling with town centre shoppers after a night in the cells feels unreal. All I can think about is getting to a safe place. In a charity shop I run my hands over racks of second-hand clothes, feeling the texture of 
the cotton, linen, tweed, silk, satin, velour, velvet, and brocade, immersing myself in the colours and patterns of the fabrics. When I part the hangers, the weight of the clothes is deeply reassuring. I want to push my way through and disappear. I have no idea what to do, so I stay there, surrounded by the trappings of other people's lives, gently worn clothing, bric-a-brac, and ephemera.

Eventually I phone my partner, who is distraught. He was frightened by my outburst and tried to get support. He didn't want me to be arrested, but he had no say once the police got involved. I go home.

Later, I see my GP and explain what happened. I ask what could have caused this catastrophic loss of control. It must be more than stress at work. But she has no answer.

A few weeks pass and I go back again. "I'm having terrible problems with the menopause," I say.

"There is something that might help," my GP responds. I wait expectantly.

"Time travel."

It takes me a while to register the joke. I'm crushed.

Three years on, my partner has been critically ill, I'm being bullied at work, and my beloved dog is dying from heart failure. I've ground to a halt and I can't get going again. A former colleague emails to say she's just been diagnosed autistic. My heart jumps. We're so alike. Could I be autistic too? I have no energy to try to persuade my GP, so I pay for a private assessment. After a three month wait, I sit in a highceilinged office, watching leaves dancing on a tree outside as a psychologist explains how to prevent why autistic meltdowns happen, and how to keep myself safe. I think back to my arrest and wonder if it would have been framed as 'domestic abuse' if I'd been known to be autistic? Would I have been diverted from custody and helped?

Another three years later, as I write this, I think of all the autistic people (diagnosed, self-identified, as yet unrecognised) incarcerated in police cells, prisons, and mental health institutions. We should be treated humanely, but the need to punish us is strong. Anyone judged to deviate from the 'norm' in terms of other intersectional dimensions (gender, race, ethnicity, religion, sexual orientation, disability, social class, poverty) is at even greater jeopardy. Things could have gone very differently in custody had I not been privileged by being white, well-educated, and from a professional background. As an ex-police officer I recognised the coercive tactics I was subjected to, and managed to resist. The advantages stacked on my side got me 
released uncharged and, much later, recognised as autistic. I'd still be on a waiting list if I hadn't paid for an assessment.

Many older autistic people haven't yet been professionally diagnosed, or even selfidentified; but that doesn't mean they're leading satisfying, healthy lives. They could be found relatively easily, and offered professional or peer support. Even if they're not in crisis now, they may be in the future. They have a right to know.

Whenever someone seems to have intractable problems, autism or another type of neurodivergence is a possibility to consider. Instead, as if by default, unrecognised autistic people (especially women) get misdiagnosed with mental health conditions, or "personality disorders."

If you're autistic or otherwise neurodivergent and end up being arrested when you need help, try not to be coerced into incriminating yourself. Know your rights and don't hesitate to assert them. Seek advice from someone you trust, stay strong, and keep safe. You can get through this.

The aftermath of my night in the cells was terrible guilt and shame. It has taken me all this time to accept that I really wasn't to blame. In coming out and writing this piece, I'm freeing myself again.

\section{Rose Matthews}

Address correspondence to:

\section{rosematthews01@gmail.com}

